\title{
PENGARUH KUALITAS SISTEM, KUALITAS INFORMASI, KUALITAS PELAYANAN DAN EKSPEKTASI KINERJA TERHADAP KEPUASAN PENGGUNA DALAM PENERAPAN SISTEM TEKNOLOGI INFORMASI PADA KOPERASI DI KOTA PEMATANGSIANTAR
}

\author{
${ }^{1}$ Dedi Suhendro \\ Dosen AMIK Tunas Bangsa Pematangsiantar, Sumatera Utara-Indonesia \\ Jalan Sudirman Blok A No. 1, 2, 3 Pematangsiantar \\ E-mail : Dedi.su@amiktunasbangsa.ac.id
}

\begin{abstract}
The objective of the research was to find out the influence of independet variables (the variable of system quality the variable of information quality, the variable of service quality, and the variable of performance expectancy) simultaneously and partially had the influence on dependent variable (users' satisfaction). The population was 300 cooperatives at Pematangsiantar, and 225 of them were used as the samples, taken by using purposive sampling technique. The data were processed by using multiple linier regression analysis with an SPSS software program. The result of the hypothesis showed that independent variables (the variable of system quality, the variable of information quality, the variable of service quality and the variable of performance expectation) simultaneously had significant influence on dependent variable (the variable of users' satisfaction) at the cooperatives, Pematangsiantar. Partially, the variable of system quality, the variable of service quality and the variable of performance expectation had positive and significant influence on user's satisfaction at the cooperatives, Pematangsiantar, but the variable of information quality did no have any influence on users' satisfaction at the cooperative, Pematangsiantar
\end{abstract}

Keywords: System quality; information quality; service quality and performance expectancy; users satisfaction

\section{Pendahuluan}

Perkembangan perekonomian
nasional yang dihadapi dunia usaha
termasuk koperasi dan usaha kecil
menengah saat ini sangat cepat dan
dinamis. Koperasi merupakan salah satu
bentuk badan usaha yang sesuai dengan
kepribadian bangsa Indonesia yang pantas
untuk ditumbuhkembangkan sebagai
badan usaha penting dan bukan sebagai
alternatif terakhir. Pemerintah secara tegas
menetapkan bahwa dalam rangka
pembangunan nasional dewasa ini,
koperasi harus menjadi tulang punggung
dan wadah perekonomian rakyat.
Kebijaksanaan pemerintah ini sesuai
dengan Undang - Undang Dasar 1945
pasal 33 ayat 1 yang menyatakan bahwa

perekonomian disusun sebagai usaha bersama berdasarkan asas kekeluargaan. Persoalan ini mengharuskan koperasi untuk melakukan upaya demi menstabilkan atau lebih meningkatkan eksistensi usahanya. Agar dapat bertahan dan mampu bersaing dengan lembaga keuangan lainnya, maka koperasi tersebut harus dapat menentukan suatu kebijakan dan strategi yang terus dikembangkan dan ditingkatkan. Salah satu kebijakan yang dapat diambil untuk membantu pengembangan koperasi adalah dengan meningkatkan efektifitas melalui penerapan Teknologi Informasi.

Penerapan teknologi informasi dalam badan usaha koperasi sudah dipandang perlu untuk diimplementasikan, 
dimana implementasi penggunaan teknologi akan memberikan banyak kemudahan dan keuntungan dalam pengembangan usaha koperasi itu sendiri. Sentuhan teknologi informasi yang beralih dari sistem pembukuan manual ke sistem teknologi informasi yang terintegrasi membawa pada perubahan koperasi guna mensejahterakan anggota dan masyarakat sehingga dapat meningkatkan performa, baik pelayanan terhadap masyarakat, kebutuhan anggota dan meningkatkan daya saing koperasi. Pelaksanaan program koperasi modern dilaksanakan secara bertahap dan berdasarkan skala prioritas dan mencakup seluruh wilayah Indonesia. Pemilihan koperasi sebagai peserta koperasi modern dilakukan berdasarkan pendekatan, diantaranya koperasi yang memiliki perangkat keras sebagai support untuk aplikasi online, memiliki tenaga staff ahli bidang teknologi yang memadai.

Manfaat dan hasil akhir yang diharapkan dari keikutsertaan koperasi dalam program koperasi modern ini adalah koperasi dapat menggunakan teknologi informasi untuk mendukung perkembangan koperasi sehingga dapat melakukan monitoring, evaluasi dan penataan yang akurat serta up to date yang dapat meningkatkan kesejahteraan anggota. Pemanfaatan dan penerapan teknologi informasi ini dapat meningkatkan kinerja koperasi hingga menjadi koperasi yang sehat, kuat, mandiri dan berkembang.

Tujuan dari penelitian ini adalah untuk menguji dan menganalisis pengaruh kualitas sistem, kualitas informasi, kualitas pelayanan dan ekspektasi kinerja terhadap kepuasan pengguna dalam penerapan sistem teknologi informasi pada koperasi di kota pematangsiantar secara simultan dan parsial.

Penelitian ini merupakan replikasi dari penelitian yang dilakukan oleh Negash, Ryan dan Igbaria (2003). Penelitian sebelumnya hanya menggunakan kualitas sistem, kualitas informasi dan kualitas pelayanan, hasil penelitian dari peneliti sebelumnya dimana kualitas sistem mempunyai hubungan positif terhadap efektivitas sistem dukungan pelanggan berbasis WEB, kualitas informasi mempunyai hubungan positif terhadap efektivitas sistem dukungan pelanggan berbasis WEB dan kualitas pelayanan berhubungan positif terhadap efektivitas sistem dukungan pelanggan berbasis WEB.

Penelitian ini menambahkan satu variabel independen yaitu variabel ekspektasi kinerja karena untuk melihat tingkat dimana seorang pengguna sistem informasi meyakini bahwa menggunakan sistem akan membantu dalam meningkatkan kinerjanya.

\section{Kajian Teori}

Beberapa peneliti terdahulu yang dapat dijadikan dasar dalam melakukan penelitian adalah sebagai berikut :

Mahendra dan Affandy (2012), meneliti tentang Faktor-Faktor yang Mempengaruhi Minat Pemanfaatan Sistem Informasi Pengelola Keuangan Daerah (SIPKD). Hasil penelitian ini menunjukkan bahwa ekspektasi kinerja mempunyai pengaruh signifikan terhadap minat pemanfaatan sistem informasi pengelola keuangan daerah (SIPKD), ekspektasi usaha mempunyai pengaruh signifikan terhadap minat pemanfaatan sistem informasi pengelola keuangan daerah (SIPKD) dan faktor sosial mempunyai pengaruh signifikan terhadap minat pemanfaatan sistem informasi pengelola keuangan daerah (SIPKD).

DeLone dan Mclean (1992), dengan judul penelitian: "Information Systems Success: The Quest for the Dependent Variable". Hasil dari penelitian ini adalah menjelaskan bahwa kualitas sistem (system quality) dan kualitas informasi (information quality) secara independen dan bersamaan mempengaruhi kepuasan pemakai (user satisfaction). 
DeLone dan Mclean (2003), dengan judul penelitian: "The DeLone and McLean Model of Information Systems Success: A Ten-Year Update" Hasil dari penelitian ini adalah menjelaskan bahwa kualitas sistem (system quality), kualitas informasi (information quality) dan kualitas pelayanan (service quality) secara independen dan bersamaan mempengaruhi kepuasan pemakai (user satisfaction).

Dody dan Zulaikha (2007) melakukan Pengujian model Delone and McLean dalam pengembangan sistem informasi manajemen. Hasil penelitian ini menunjukkan bahwa intensitas penggunaan sistem informasi berpengaruh positif signifikan terhadap individual impact, sedangkan individual impact berpengaruh positif signifikan terhadap organizational impact. Kualitas informasi dan kualitas sistem tidak berpengaruh signifikan terhadap intensitas penggunaan sistem infromasi dan user satisfaction.

Septriani (2010) meneliti tentang Pengaruh Kinerja Sistem Terhadap Kepuasan Pengguna Pada PT. Bank Muamalat Indonesia (Tbk). Hasil penelitian nya adalah variabel kapabilitas/ kemampuan personal, variabel dukungan manajemen puncak, dan variabel keberadaan dewan pengarah yang mempunyai pengaruh secara positif signifikan terhadap kepuasan pengguna. Variabel-variabel lainnya yaitu: variabel keterlibatan pemakai, variabel ukuran organisasi, variabel formalisasi pengembangan sistem, variabel program pelatihan dan pendidikan, dan variabel lokasi departemen sistem informasi, tidak memiliki pengaruh positif signifikan terhadap kepuasan pengguna.

$$
\text { Handayani (2005) melakukan }
$$

penelitian tentang Analisis Faktor-Faktor yang Mempengaruhi Minat Pemanfaatan Sistem Informasi dan Penggunaan Sistem Informasi. Hasil penelitian ini menunjukkan bahwa variabel ekspektasi kinerja mempunyai pengaruh positif signifikan terhadap minat pemanfaatan
Sistem Informasi, variabel ekspektasi usaha berpengaruh positif dan signifikan terhadap minat pemanfaatan Sistem Informasi, variabel faktor sosial berpengaruh positif signifikan terhadap minat pemanfaatan Sistem Informasi, variabel kondisi-kondisi yang memfasilitasi pemakai terbukti mempunyai pengaruh positif dan signifikan terhadap penggunaan Sistem Informasi, dan variabel kondisi-kondisi yang memfasilitasi pemakai terbukti mempunyai pengaruh positif dan signifikan terhadap penggunaan Sistem Informasi, variabel minat pemanfaatan Sistem Informasi berpengaruh positif dan tidak signifikan terhadap penggunaan Sistem Informasi.

Gorla, Somers, Wongs (2010) melakukan penelitian tentang "Organizational impact of system quality, information quality, and service quality". Kualitas sistem berhubungan positif dengan dampak organisasi, kualitas sistem secara positif berhubungan dengan kualitas informasi, kualitas informasi berhubungan positif dengan dampak organisasi dan kualitas pelayanan secara positif terkait dengan dampak organisasi.

Saleh, Darwanis dan Bakar (2012) melakukan penelitian untuk mengetahui pengaruh kualitas sistem informasi terhadap kualitas informasi akuntansi dalam upaya meningkatkan kepuasan pengguna software akuntasi pada pemerintah Aceh. Hasil penelitian ini menunjukkan bahwa Kualitas sistem informasi berpengaruh terhadap kualitas informasi akuntansi akuntansi. semakin baik sistem informasi yang dijalankan akan menghasilkan informasi yang handal, relevan, tepat waktu dan dapat diandalkan. Kualitas sistem informasi berpengaruh terhadap kepuasan pengguna software akuntansi. semakin baik sistem informasi yang dijalankan semakin meningkatkan kepuasan pengguna software akuntansi. Kualitas informasi akuntansi berpengaruh terhadap kepuasan pengguna software 
akuntansi. informasi yang berkualitas memberikan informasi yang akurat, jelas, detil, relevan, mudah diterapkan, mudah didapatkan, tepat waktu, up to date dan sesuai dengan kebutuhan pengguna sehingga meningkatkan kepuasan pengguna dalam menggunakan informasi yang dihasilkan. Kualitas sistem informasi dan kualitas informasi akuntansi secara simultan berpengaruh terhadap kepuasan pengguna software akuntansi.

Kualitas sistem berarti kualitas dari kombinasi hardware dan software dalam sistem informasi. Fokusnya adalah performa dari sistem, yang merujuk pada seberapa baik kemampuan perangkat keras, perangkat lunak, kebijakan, prosedur dari sistem informasi dapat menyediakan informasi kebutuhan pengguna (DeLone dan McLean, 1992).

Kualitas informasi merujuk pada output dari sistem informasi, menyangkut nilai, manfaat, relevansi, dan urgensi dari informasi yang dihasilkan (Pitt dan Watson 1997).

Kualitas pelayanan (Information Quality) pada dasarnya dapat didefinisikan sebagai aktivitas seseorang, sekelompok dan/atau organisasi baik langsung maupun tidak langsung untuk memenuhi kebutuhan (Harbani, 2007).

Ekspektasi kinerja diyakini bahwa seorang individu akan menggunakan sistem informasi apabila sistem tersebut dapat membantunya untuk meningkatkan kinerja (Handayani, 2005).

Kerangka konsep pada penelitian ini adalah sebagai berikut :

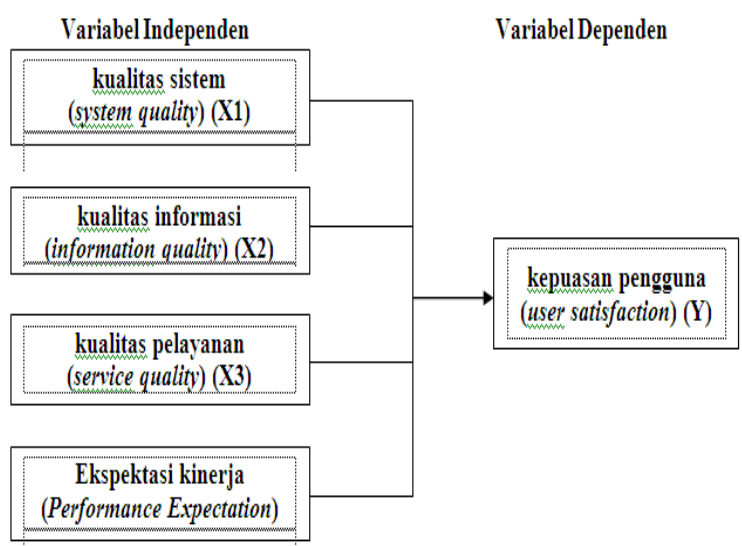

Gambar 1. Kerangka konsep penelitian

\section{Metode Penelitian}

Teknik pengumpulan data dalam penelitian ini dilakukan dengan melakukan survei lapangan yaitu dengan menyebarkan kuesioner. Kuesioner diberikan kepada internal user karyawan atau pegawai pada kantor koperasi di wilayah Pematangsiantar, terdapat 300 (tiga ratus) kantor koperasi di wilayah Pematangsiantar yang dijadikan objek penelitian. Daftar populasi koperasi yang bersumber dari dinas koperasi dan UKM kota Pematangsiantar.

Tahapan dalam penyebaran dan pengumpulan kuisioner dibagi dalam dua tahap yaitu pertama, melakukan penyebaran kuisioner kepada sampel yang digunakan dalam penelitian ini hanya internal user atau staff/pegawai pada kantor koperasi di wilayah Pematangsiantar, kemudian menunggu pengisian kuisioner tersebut. Kedua, pengambilan kuisioner yang telah diisi oleh responden untuk dilakukan pengolahan data.

Populasi penelitian ini adalah internal user atau staff/pegawai pada kantor koperasi di wilayah Pematangsiantar dan terdapat 300 (tiga ratus) kantor koperasi di wilayah Pematangsiantar yang dijadikan objek penelitian.

Metode pemilihan sampel yang digunakan dalam penelitian ini adalah "Purposive Sampling yaitu penarikan sampel dengan pertimbangan tertentu" (Suharyadi, 2004:332). Pertimbangan tersebut didasarkan pada kepentingan atau tujuan penelitian. Sampel yang akan digunakan dalam penelitian ini hanya internal user atau staff/pegawai pada 
kantor koperasi di wilayah Pematangsiantar yang berjumlah 225 (dua ratus dua puluh lima), yang memenuhi kriteria sebagai berikut:

1. Kantor koperasi di wilayah Pematangsiantar yang telah memiliki sistem teknologi informasi

2. Staff/pegawai pada bidang sistem teknologi informasi yang bekerja pada kantor koperasi di wilayah Pematangsiantar dan mempunyai pengalaman kerja minimal dua tahun. Dipilih telah bekerja dua tahun, karena telah memiliki waktu dan pengalaman untuk beradaptasi serta menilai kondisi lingkungan kerjanya.

Variabel dependen dalam penelitian ini adalah kepuasan pengguna (user satisfaction) merupakan respon pemakai terhadap penggunaan keluaran sistem informasi.

Variabel Independen :

1. Kualitas sistem (system quality) adalah kualitas dari kombinasi perangkat keras

(hardware) dan perangkat lunak (software) dalam sistem informasi

2. Kualitas Informasi mengacu pada kualitas output atau keluaran dari sistem yang menghasilkan informasi kepada pengguna

3. Kualitas layanan (service quality) adalah suatu kegiatan yang terjadi dalam interaksi langsung antara seseorang dengan orang lain atau mesin secara fisik, dan menyediakan kepuasaan pelanggan

4. Eskpektasi kinerja merupakan tingkat dimana seorang individu meyakini bahwa dengan menggunakan sistem informasi akan membantu dalam meningkatkan kinerjanya

\section{Hasil dan Pembahasan}

Uji Hipotesis Koefisien Determinasi

Koefisien Determinasi untuk mengetahui seberapa besar kemampuan variabel independen dalam menjelaskan variabel dependen maka digunakan koefisien determinasi (Adjusted $R$ square)

Tabel 1. Koefisien Determinasi $\left(\mathrm{R}^{2}\right)$

Model Summary

\begin{tabular}{lcccc}
\hline Model & $\mathrm{R}$ & $\mathrm{R}$ Square & $\begin{array}{c}\text { Adjusted R } \\
\text { Square }\end{array}$ & $\begin{array}{c}\text { Std. Error of the } \\
\text { Estimate }\end{array}$ \\
\hline 1 &, $821^{\text {a }}$ &, 674 &, 668 & 2,571 \\
\hline a. Predictors: (Constant), Ekspektasi Kinerja, Kualitas Sistem, \\
Kualitas Pelayanan, Kualitas & Informasi \\
b. Dependent Variable: Kepuasan Pengguna \\
\hline
\end{tabular}

Nilai koefisien determinasi $\left(\mathrm{R}^{2}\right)$ $67,4 \%$ hal ini berarti $67,4 \%$ variabel kepuasan pengguna yang bisa dijelaskan oleh variasi dari keempat variabel independen (kualitas sistem, kualitas informasi, kualitas pelayanan dan ekspektasi kinerja), sedangkan sisanya sebesar 32,6\% dipengaruhi dan dijelaskan oleh variabel lain yang tidak masuk dalam model penelitian ini. Penelitian ini sangat dimungkinkan pada variabel kepuasan pengguna tidak hanya dipengaruhi oleh faktor fundamental yang diwakili oleh keempat rasio tersebut, namun kepuasan pengguna juga dipengaruhi variabel lainnya lain diluar model yang diuji dalam penelitian ini.

\section{Pengujian Hipotesis Simultan (Uji F)}

Pengujian ini dilakukan untuk mengetahui apakah semua variabel independen secara bersama-sama (simultan) dapat berpengaruh terhadap variabel dependen. Berdasarkan Hasil pengolahan data, maka diperoleh hasil sebagai berikut : 
Berdasarkan hasil perhitungan diperoleh nilai $F_{\text {hitung }}$ sebesar 113,610 dan nilai signifikansi sebesar 0.000. Hasil dapat dilihat dari Tabel. 2 dibawah ini:

Tabel 2. Hasil Pengujian Hipotesis Simultan (Uji F)

\begin{tabular}{|c|c|c|c|c|c|c|}
\hline & \multicolumn{6}{|c|}{ ANOVA $^{\mathrm{a}}$} \\
\hline & Model & $\begin{array}{l}\text { Sum of } \\
\text { Squares }\end{array}$ & df & $\begin{array}{c}\text { Mean } \\
\text { Square }\end{array}$ & $\mathrm{F}$ & Sig. \\
\hline \multirow{3}{*}{1} & Regression & 3004,243 & 4 & 751,061 & 113,610 &, $000^{\mathrm{b}}$ \\
\hline & Residual & 1454,397 & 220 & 6,611 & & \\
\hline & Total & 4458,640 & 224 & & & \\
\hline
\end{tabular}

a. Dependent Variable: Kepuasan Pengguna

b. Predictors: (Constant), Ekspektasi Kinerja, Kualitas Sistem, Kualitas Pelayanan, Kualitas Informasi

Berdasarkan Tabel. 2 Nilai $F$ hitung adalah 113,610. Dengan tingkat signifikansi, $\mathrm{a}=5 \%$, df pembilang $=\mathrm{k}-1=$ $5-1=4$, df penyebut $=\mathrm{N}-\mathrm{k}=225-5=$ 220 , df Total $=\mathrm{N}-1=225-1=224(\mathrm{k}$ adalah jumlah banyaknya variabel, $\mathrm{N}$ adalah jumlah banyaknya sampel ). Hasil diperoleh untuk nilai $\mathrm{F}$ tabel sebesar 2,41 maka, $F_{\text {hitung }}>F_{\text {tabel }}(113,610>2,41)$

$\mathrm{F}_{\text {hitung }}$ lebih besar dibandingkan $\mathrm{F}_{\text {tabel }}$, dengan tingkat signifikansi sebesar 0,000 yang lebih kecil dari 0,05 , maka $\mathrm{H}_{0}$ ditolak, ini berarti bahwa variabel independen (kualitas sistem, kualitas informasi, kualitas pelayanan dan ekspektasi kinerja) tersebut secara simultan berpengaruh signifikan terhadap variabel dependen (kepuasan pengguna) artinya besar kecilnya keempat rasio tersebut secara simultan mempengaruhi kepuasan pengguna.

\section{Pengujian Hipotesis Secara Parsial (Uji t)}

Pengujian hipotesis secara parsial ini dilakukan untuk mengetahui apakah masing-masing variabel independen (kualitas sistem, kualitas informasi, kualitas pelayanan dan ekspektasi kinerja) berpengaruh terhadap variabel dependen (kepuasan pengguna). Berdasarkan hasil pengolahan data, maka diperoleh hasil sebagai berikut:

Tabel 3. Hasil Pengujian Hipotesis Secara Parsial (Uji t) Coefficients $^{\mathrm{a}}$

\begin{tabular}{|c|c|c|c|c|c|c|}
\hline & \multirow[t]{2}{*}{ Model } & \multicolumn{2}{|c|}{$\begin{array}{l}\text { Unstandardized } \\
\text { Coefficients }\end{array}$} & \multirow{2}{*}{$\begin{array}{c}\text { Standardized } \\
\text { Coefficients } \\
\text { Beta } \\
\end{array}$} & \multirow[t]{2}{*}{$\mathrm{t}$} & \multirow[t]{2}{*}{ Sig. } \\
\hline & & $\mathrm{B}$ & Std. Error & & & \\
\hline \multirow{5}{*}{1} & (Constant) & $-1,051$ & ,913 & & $-1,152$ & ,251 \\
\hline & Kualitas Sistem & ,099 & ,033 & ,191 & 2,989 & ,003 \\
\hline & Kualitas Informasi & 081 & ,051 & ,113 & 1,601 & ,111 \\
\hline & Kualitas Pelayanan & ,383 & ,071 & ,313 & 5,415 & ,000 \\
\hline & Ekspektasi Kinerja & 322 & 070 & ,312 & 4,635 &, 000 \\
\hline
\end{tabular}

a. Dependent Variable: Kepuasan Pengguna 
Berdasarkan Tabel 3 maka dapat disusun persamaan regresi linear berganda sebagai berikut :

$$
\begin{gathered}
Y=\alpha+\beta_{1} X_{1}+\beta_{2} X_{2}+\beta_{3} X_{3}+\beta_{4} X_{4}+\varepsilon \\
Y=-1,051+0,099 X_{1}+0,081 X_{2}+0,383 X_{3}+0,322 X_{4}
\end{gathered}
$$

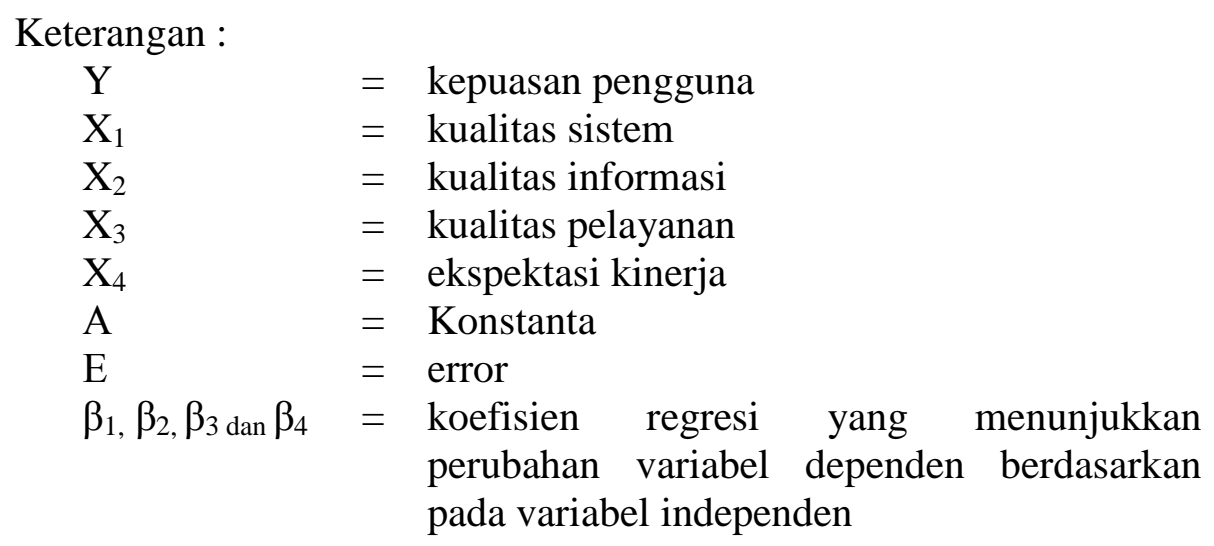

Berdasarkan hasil pengolahan data pada tabel 3 diatas, maka secara parsial pengaruh masing-masing variabel independen terhadap variabel dependen adalah sebagai berikut:

1. Variabel Kualitas Sistem memiliki nilai $t_{\text {hitung }}$ sebesar 2,989 dan nilai $t_{\text {tabel }}$ $(0,025 ; 225) \quad$ sebesar 1,971. Dengan demikian $t_{\text {hitung }}>t_{\text {tabel }}$ yaitu 2,989>1,971 maka $\mathrm{H}_{0}$ ditolak, yang berarti bahwa variabel Kualitas Sistem berpengaruh positif dan signifikan terhadap Kepuasan Pengguna pada Koperasi di Kota Pematangsiantar.

2. Variabel Kualitas Informasi memiliki nilai $t_{\text {hitung }}$ sebesar 1,601 dan nilai $t_{\text {tabel }}$ sebesar 1,971. Dengan demikian $t_{\text {hitung }}$ $<\mathrm{t}_{\text {tabel }}$ yaitu $1,601<1,971$ maka $\mathrm{H}_{0}$ diterima, yang berarti bahwa variabel Kualitas Informasi tidak berpengaruh terhadap Kepuasan Pengguna pada Koperasi di Kota Pematangsiantar.

3. Variabel Kualitas Pelayanan memiliki nilai $t_{\text {hitung }}$ sebesar 5,415 dan nilai $t_{\text {tabel }}$ sebesar 1,971. Dengan demikian $t_{\text {hitung }}$ $>\mathrm{t}_{\text {tabel }}$ yaitu 5,415> 1,971 maka $\mathrm{H}_{0}$ ditolak, yang berarti bahwa variabel Kualitas Pelayanan berpengaruhi positif dan signifikan terhadap Kepuasan
Pengguna pada Koperasi di Kota Pematangsiantar.

4. Variabel Ekspektasi Kinerja memiliki nilai $t_{\text {hitung }}$ sebesar 4,635 dan nilai $t_{\text {tabel }}$ sebesar 1,971. Dengan demikian $t_{\text {hitung }}$ $>\mathrm{t}_{\text {tabel }}$ yaitu 4,635> 1,971 maka $\mathrm{H}_{0}$ ditolak, yang berarti bahwa variabel Ekspektasi Kinerja berpengaruh positif dan signifikan terhadap Kepuasan Pengguna pada Koperasi di Kota Pematangsiantar.

\section{Kesimpulan}

Hasil hipotesis mengenai pengaruh kualitas sistem, kualitas informasi, kualitas pelayanan dan ekspektasi kinerja maka diperoleh hasil secara simultan variabel kualitas sistem, kualitas informasi, kualitas pelayanan dan ekspektasi kinerja berpengaruh signifikan terhadap kepuasan pengguna. Secara parsial menunjukkan bahwa kualitas sistem berpengaruh positif dan signifikan terhadap kepuasan pengguna. Diprediksi bahwa semakin tinggi kualitas sistem yang digunakan, akan berpengaruh terhadap semakin tinggi tingkat kepuasan pengguna. Secara parsial menunjukkan bahwa variabel kualitas informasi tidak berpengaruh terhadap kepuasan pengguna. Hal ini menunjukkan 
bahwa informasi tidak akurat dan tidak tepat sasaran dalam mengambil keputusan karena responden kurang mempunyai niat dan minat serta tidak memiliki kemampuan untuk memanfaatkan sistem yang ada dalam koperasi sehingga penggunaan sistem tidak mencapai hasil output atau keluaran yang maksimal. Secara parsial menunjukkan bahwa variabel kualitas pelayanan berpengaruh positif dan signifikan terhadap kepuasan pengguna. Variabel ekspektasi kinerja berpengaruh positif dan signifikan terhadap kepuasan pengguna.

Keterbatasan dalam menggunakan faktor - faktor fundamental yang diwakili dari keempat variabel independen (kualitas sistem, kualitas informasi, kualitas pelayanan dan ekspektasi kinerja), dengan kemungkinan masih banyak lagi faktor faktor lain yang berpengaruh terhadap kepuasan pengguna. Pemilihan metode pengumpulan data yaitu dengan metode survei, yang mana metode survei mengandung kelemahan karena dalam pengisian jawaban pada kuesioner tidak mencerminkan keadaan sebenarnya atau sesungguhnya terjadi sehingga kurang fleksibel.

\section{Daftar Pustaka}

Aldillah Reza Mahendra dan Didied Poernawan Affandy. 2012. FaktorFaktor yang Mempengaruhi Minat Pemanfaatan Sistem Informasi Pengelola Keuangan Daerah (SIPKD). Malang, Universitas Brawijaya

DeLone, W.H. and E.R.Mc Lean. 1992. Information System Success: The Quest for the Dependent Variable, Information System Research 3 (Marach)

DeLone, W.H. and E.R.Mc Lean. 2003. The DeLone and McLean Model of Information Systems Success: A Ten-Year Update, Journal of Management Information Systems /
Spring 2003, Vol. 19, No. 4, pp. 930

Dody Radityo dan Zulaikha. 2007. Pengujian Model DeLone and McLean Dalam Pengembangan Sistem Informasi Manajemen, Simposium Nasional Akuntansi X

Evy Septriani. 2010. Pengaruh Kinerja Sistem Terhadap Kepuasan Pengguna Pada PT. Bank Muamalat Indonesia (Tbk) [tesis] Jakarta: Universitas Gunadarma

Narasimhaiah Gorla, Toni M. Somers, Betty Wong. 2010. Organizational impact of system quality, information quality and service quality. Journal of Strategic Information Systems 19 (2010) 207-228

Pasolong Harbani. 2007. Teori Administrasi Publik, Bandung, CV. Alfabeta

Pitt, Leyland F.; Watson, Richard T. 1997. Measuring Information Systems Service Quality: Concerns For A Complete Canvas. MIS Quarterly, 21 (2): 209-222.

Rini Handayani. 2005. Analisis faktorfaktor yang mempengaruhi minat pemanfaatan sistem informasi dan penggunaan sistem informasi (studi empiris pada perusahaan manufaktur di bursa efek jakarta) [Tesis] Semarang: Universitas Diponegoro

Solomon Negash, Terry Ryan dan Magid Igbaria. 2002. Quality and effectiveness in Web-based customer support systems.

Suharyadi. 2004. Manajemen Penelitian, Rineka cipta, Jakarta. 